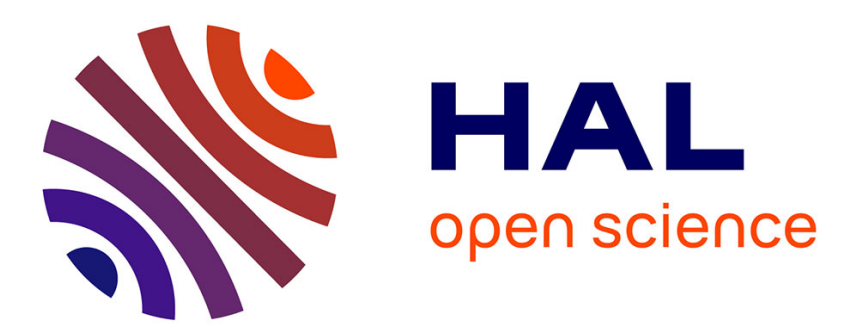

\title{
Pop-down tectonics, fluid channelling and ore deposits within ancient hot orogens
}

Denis Gapais, Justine Jaguin, Florence Cagnard, Philippe Boulvais

\section{To cite this version:}

Denis Gapais, Justine Jaguin, Florence Cagnard, Philippe Boulvais. Pop-down tectonics, fluid channelling and ore deposits within ancient hot orogens. Tectonophysics, 2014, 618, pp.102-106. 10.1016/j.tecto.2014.01.027 . insu-00965100

\section{HAL Id: insu-00965100 \\ https://hal-insu.archives-ouvertes.fr/insu-00965100}

Submitted on 24 Mar 2014

HAL is a multi-disciplinary open access archive for the deposit and dissemination of scientific research documents, whether they are published or not. The documents may come from teaching and research institutions in France or abroad, or from public or private research centers.
L'archive ouverte pluridisciplinaire HAL, est destinée au dépôt et à la diffusion de documents scientifiques de niveau recherche, publiés ou non, émanant des établissements d'enseignement et de recherche français ou étrangers, des laboratoires publics ou privés. 


\title{
POP-DOWN TECTONICS, FLUID CHANNELLING AND ORE DEPOSITS WITHIN ANCIENT HOT OROGENS
}

\author{
Denis Gapais ${ }^{\mathrm{a}^{*}}$, Justine Jaguin ${ }^{\mathrm{a}}$, Florence Cagnard ${ }^{\mathrm{b}}$, Philippe Boulvais ${ }^{\mathrm{a}}$ \\ ${ }^{a}$ Géosciences Rennes, UMR CNRS 6118, Université de Rennes 1, 35042 Rennes cedex, \\ France. \\ ${ }^{\mathrm{b}}$ BRGM, 3 Avenue Claude Guillemin, BP 36009, 45060 Orléans cedex 2, France. \\ Corresponding author: denis.gapais@univ-rennes1.fr. Phone 0033 (0)6 20015869
}




\section{ABSTRACT}

Many Archaean and Paleoproterozoic deformation zones, often rich in ore resources, show particular structural patterns in particular marked by regional vertical stretch. These zones are not restricted to greenstone-bearing Archaean domains that may have suffered gravity-driven sagduction of heavy supra-crustals, as extensively discussed since the last twenties. Structures are actually best explained by pop-down tectonics of upper-crustal units within an underlying weak crust submitted to horizontal regional shortening. Here we present three complementary examples from two Archaean greenstone belts (Abitibi sub-Province, Quebec, and Murchison belt, South Africa) and one greenstone-lacking Paleoproterozoic belt (Thompson belt, Manitoba). In the three examples, ore is concentrated along steeply dipping deformation zones, rich in syntectonic deposits and marked by substantial sub-vertical crustal stretch. On the other hand, the three regions show differences in age, in metamorphic grade (from sub-greenschist facies to upper amphibolite facies), in metal contents (gold, antimony, nickel), in metal sources, transfers and concentration histories. Our analysis emphasizes that pop-down tectonics associated with horizontal shortening of weak lithospheres may account for observed structural patterns and provides a new and promising frame for the analysis of relationships between structural patterns and ore concentrations within old cratons.

Key words: Tectonics, crustal shortening, weak lithosphere, fluid transfers, ore deposits, ancient cratons 


\section{Introduction}

Tectonics that structured Precambrian cratons is a major ongoing debate in Earth Sciences. This relates to academic reasons linked to long-lasting and still debated controversies about the modes of lithospheric deformations through geological times (Choukroune et al. 1995; Burg and Ford, 1997; Windley, 1997; Hamilton, 2003; Chardon et al., 2009; Gapais et al., 2009; Ganne et al., 2011), and to economic ones, Precambrian cratons being particularly rich in ore concentrations.

Archaean and Paleoproterozoic cratons have remarkable structural specificities (Choukroune et al., 1995; Chardon et al., 2009; Gapais, et al., 2009). In particular, strains marked by steeply dipping fabrics often bearing steeply plunging stretching lineations are widespread, from low grade upper crust to deeper granulitic and partial melting conditions (Hudleston et al., 1988; Fueten and Robin, 1989; Goscombe, 1991; Chown et al., 1992; Bouhallier et al., 1995; Choukroune et al., 1995; Lonka et al., 1998; Chardon et al., 2002, 2008, 2009; Cagnard et al., 2006a, 2007; Gapais et al., 2008; Jaguin et al., 2012). These regions contain deformation bands that show large strains despite lacks of major metamorphic jumps (Chown et al., 1992; Bleeker, 1990; Vearncombe et al., 1992; Powell et al., 1995; Gapais et al., 2005; Jaguin et al., 2012), and some are marked by important ore concentrations (Bleeker, 1990; Vearncombe et al., 1992; Chardon et al., 2002; Gapais et al., 2005; Böhm et al., 2007; Dubé and Gosselin, 2007; Jaguin et al., 2012; Lin and Beakhouse, 2013). Recent analogue experiments and field surveys have argued that vertical tectonics, marked by downward motion of upper-crustal rocks within a weak ductile underlying crust was a major mode of shortening of hot lithospheres (Cagnard et al., 2006a, b; Chardon et al., 2009 and refs. therein; Gapais et al., 2009).

In this paper, we compare three orogenic sub-provinces marked by different metal contents: the Southernmost Abitibi Greenstone Belt (Abitibi Sub-Province, Quebec) 
$(\mathrm{Au})$, the Antimony line within the Murchison Greenstone Belt (South Africa) (Sb), and the Thompson Nickel Belt (Canada) (Ni). Beside their different metal contents, the areas range from Archaean (Abitibi and Murchison belts) to Paleoproterozoic in age

(Thompson belt). They further show different metamorphic grades, sub-greenschist facies to greenschist facies in southernmost Abitibi (Powell et al., 1995), greenschist facies along the Antimony Line in the Murchison belt (Vearncombe et al., 1992), upperamphibolite facies, up to partial melting and granulitic conditions, in the Thompson belt (Bleeker, 1990; Zwanzig et al., 2007 and refs therein).

Our paper emphasizes that pop-down tectonics marked by downward motions of faultbounded upper crustal blocks was common during horizontal compression of weak continental lithospheres and may have been a first-order factor accounting for channelled fluid transfers and concentrations of ore deposits in ancient deformation belts.

\section{Geology, structure, and ore deposits}

At the map scale, the three examples show two first-order characteristics (Figs. 1 and 2). First, foliations are mainly steeply dipping, strike parallel to the belt (locally disturbed by syn-kinematic intrusions), and bear widespread steeply plunging lineations attesting to sub-vertical stretch; second, ore deposits are concentrated within or around belt-parallel alignments of supra-crustals (sediments or volcanics) and along narrow deformation zones parallel to the belts (Chown et al., 1992; Vearncombe et al., 1992; Gapais et al., 2005; Böhm et al., 2007; Dubé and Gosselin, 2007; Jaguin et al., 2012).

In the southernmost Quebec Abitibi sub-Province, major gold deposits mark the E-W striking steeply dipping Cadillac deformation zone that separates the Abitibi Greenstone Belt from the Pontiac domain to the South (Fig. 1a). Other E-W striking deformation zones also marked out by supra-crustals and gold deposits occur within the belt to the 
North (Fig. 1A) (Dubé and Gosselin, 2007). Evidence for vertical stretch components is widespread throughout the region (Chown et al., 1992; Dubé and Gosselin, 2007) (Fig. 2a, b) where kinematics involved dominant top-to-the-South motions in an overall transpressive context (Chown et al., 1992). However, metamorphic and structural data attest to limited syn-transpression offsets along the Cadillac zone (Chown et al., 1992; Powell et al., 1995; Dubé and Gosselin, 2007). Gold concentrations are also observed along NW-SE striking zones recognized as late dextral strike-slip zones that offset lithologies to a maximum extend of the order of $10^{\text {th }}$ of $\mathrm{km}$ (Chown et al., 1992, Dubé and Gosselin, 2007) (Fig. 1a). Gold is concentrated in quartz-carbonate \pm tourmaline veins (Dubé and Gosselin, 2007; Tremblay, 2011).

In the Murchison belt, sub-vertical fabrics bearing steeply plunging stretching lineations affect the entire belt, ore deposits being concentrated in quartz-carbonate veins along the so-called Antimony Line (Vearncombe et al., 1992) (Figs. 1b and 2b, c). At the regional scale, sub-vertical fabrics are associated with top-to-the-South motions with minor transpressive components and limited displacements along the Antimony line (Vearncombe et al., 1992; Jaguin et al. 2012).

In the Thompson belt, Ni resources are mainly concentrated within sulphide facies iron Formations at the vicinity of shear zones that cut across at low angle or bound supracrustal metasediments along the western margin of the belt (Böhm et al., 2007; Zwanzig et al., 2007) (Fig. 1c). These zones appear as latest active deformation zones within the belt that is marked by pervasive sub-vertical foliations bearing steeply plunging lineations (Fueten and Robin, 1989; Bleeker, 1990; Gapais et al., 2005) (Figs. 1c and 2e, f). The regional deformation was transpressive, with vertical components pointing to overall top-to-the West motions, combined with minor dextral wrenching (Fueten and Robin, 1989; Gapais et al., 2005). 


\section{A general model}

None of the mineralized lineaments show evidence of major displacements along thrusts or normal detachments that would be marked by important metamorphic jumps. They neither point to important wrench-type displacements that would be marked by pervasive horizontal stretching lineations and by significant horizontal offsets of tectonic units recorded at the map scale. Field evidence and analogue models have actually shown that shortening of weak lithospheres results in dominant vertical tectonics (Cagnard et al., 2006; Gapais et al., 2005, 2008, 2009; Cagnard et al., 2006a, b, 2007; Chardon et al., 2009) (Fig. 3b), Analogue models have further shown that the onset of a local pop-down resulted in strain concentration and triggered the piling-up of other upper crustal popdowns along vertical deformation zones (Cagnard et al., 2006a).

Figure 3a shows our general model of tectonics, fluid flow and mineralization interactions at crustal scale, on the basis of analogue modelling of shortening of a weak lithosphere bearing a ductile lithospheric mantle (Fig. 3b). Syntectonic sediments concentrate within spaces provided at fault footwalls during first stages of pop-down motions of upper crust pieces. During their downward motion, upper-crustals are affected by ductile deformations. Fluids are produced during progressive burial through successive compaction, diagenesis, and metamorphic and melting reactions, steeply dipping foliations and shear planes favouring efficient upward circulation (Sibson et al., 1988) (Fig. 3a). As a positive feedback, fluid-induced strain weakening may contribute to further strain concentration along zones of pop-down piling-up. The final result of deformation-fluid interactions is the development of high-angle channels for localised fluid circulation (Sibson et al., 1988; Lin and Beakhouse, 2013) where large permeability is maintained at the grain scale by high strains (Putnis, 2002). Mineral depositions may 
further concentrate in second order structures as small-scale tension gashes or pull-apart

Various fluid sources may be sampled during the process, from the crust surface to the mantle, provided deformation channels are long enough to connect potential reservoirs. $\mathrm{CO}_{2}$ degassing from the mantle has for example be documented within large shear zones of southern Madagascar (Pili et al., 1997), together with partial melting of the lower crust in the region (Morteani et al., 2013; Martin et al., in press). As fluids of distinct origins may become connected within zones of high strains, chemical disequilibria occur at their meeting point, a classical mechanism for metal precipitation. For gold, mixing between oxidizing surface-derived fluids and Au-bearing deep fluids (e.g. Beaudoin and Pitre, 2005) may for example induce the destabilisation of Au-bearing sulphide complexes by redox changes (e.g. Shenberg and Barnes, 1989).

Geometric relationships between strain patterns associating vertical motions, alignments of supra-crustals rocks and ore deposits comparable to those described here have been reported for other Archaean domains (Chardon et al., 2002; Lin and Beakhouse, 2013). However, attached interpretations were made in the light of models based on gravity-driven sinking (sagduction) of heavy greenstone belts within an underlying light and weak felsic crust (Raleigh-Taylor instabilities) (Choukroune et al., 1995; Chardon et al., 2002; Lin and Beakhouse, 2013). On the other hand, analogue models with normal density profiles increasing from top to bottom (Cagnard et al., 2006a, b; Gapais et al., 2009) (Fig. 3b), and field evidence from Paleoproterozoic areas where heavy greenstone belts are lacking (Cagnard et al., 2006a; Gapais et al., 2005; 2008, 2009) demonstrated that pop-down tectonics as invoked here just required an underlying weak and hot lithosphere with a ductile sub-Moho mantle, and a regional compressive horizontal stress field. Gravity-driven sagduction of heavy greenstones deposited on a 
buoyant felsic crust may combine with pop-down tectonics and thus further favour downward motion of supra-crustals units (Chardon et al., 2009).

The three studied areas show first-order structural correlations between ore concentrations, regional-scale horizontal shortening involving important sub-vertical crustal stretch, and strain concentration along steeply dipping zones (Figs. 1 and 2), their location having possibly been influenced by pre-existing discontinuities, like boundaries of accreting terrains (Bleeker, 1990; Chown et al., 1992; Vearncombe et al., 1992). The three areas host distinct metal deposits $(\mathrm{Au}, \mathrm{Sb}, \mathrm{Ni})$, notably because of distinct pressuretemperature conditions of mineralization. Another reason for this may lie in the fact that the local lithologies involved in the deformation history were enriched in a specific metal before the mineralization event. $\mathrm{Ni}$ is abundant in the ultramafics of the Thompson belt before its trapping in the iron formations (Zwantzig et al., 2007); metasediments of the Weigel Formation in the core of the Murchison belt are anomalously enriched in $\mathrm{Sb}$ (Pearton and Viljoen, 1986); and various lithologies in the Abitibi greenstone belt may have provided Au for mineralization.

The three examples described here attest to transpressive motions during regional shortening (Chown et al., 1992; Gapais et al., 2005; Jaguin et al., 2012). Models (Cagnard et al., 2006a; Rey and Houseman, 2006) and field examples (Chardon et al., 2009 and refs. therein) have consistently shown that wrench components along such steep deformation zones may actually occur, basically because of transform motions due to horizontal longitudinal flow of the weak ductile crust that combines with regional horizontal shortening.

We show here that ore deposition does occur in quite comparable tectonic settings within greenstone-bearing Archaean belts and within younger greenstone-lacking Paleoproterozoic deformation zones. Consequently, we propose that vertical tectonics is a 
main driving process that concentrates supra-crustal materials, strains, fluid transfers, and metal transport along steeply dipping deformation zones. Reactivation of pre-existent structures may favour strain localisation and subsequent fluid and mineralization histories. It is worth noting that triple points within Archaean greenstones trapped between gneiss domes, as exemplified in the Pilbara area (Australia), show comparable relationships between vertical motions and ore concentrations (Thébaud and Rey, 2013).

Beyond further arguing for the main role of vertical tectonics during compression of hot lithospheres irrespective of their age, our analysis should provide a new and general tectonic frame for metallogenic exploration in ore-rich cratons.

\section{Acknowledgements}

D.G. thanks N. Machado, A. Potrel, M. Poujol and P. Roy for working opportunities in the three areas discussed in the paper. R. Daigneault and the Bureau de l'exploration géologique du Québec kindly allowed us to use their data of stretching lineations along the Cadillac fault zone. Stereograms were made using the software "Stereonet" (R. Allmendinger). Editors and anonymous reviewers are thanked for their constructive reviews of the initially submitted paper.

\section{References}

Beaudoin, G. Pitre, D. 2005. Stable isotope geochemistry of the Archean Val d'Or (Canada) orogenic gold vein field. Mineralium Deposita, 40, 59-75.

Bleeker, W., 1990. New structural-metamorphic constraints on early Proterozoic oblique collision along the Thompson Nickel Belt, Manitoba, Canada. In: Lewry, J.F., Stauffer, M.R. (Eds.), The Early Proterozoic Trans-Hudson Orogen of North America. Geol. Soc. Ass. Canada Spec. Paper 37, 57-73. 
Böhm, C.O., Zwanzig, H.V., Creaser, R.A. 2007. Sm-Nd Isotope Technique as An Exploration Tool: Delineating the Northern Extension of the Thompson Nickel Belt, Manitoba, Canada. Economic Geology 102, 1217-1231.

Bouhallier, H., Chardon, D., Choukroune, P., 1995. Strain patterns in Archaean dome and basin structures. the Dharwar Craton (Karnakata, South India): Earth Planet. Sci. Lett. $135,57-75$.

Burg, J.P., Ford, M., 1997. Orogeny through time: an overview. In Burg, J.P., Ford, M., (Eds.), Orogeny Through Time. Geol. Soc. London Spec. Pub. 121, 1-17.

Cagnard, F., Durrieu, N., Gapais, D., Brun, J.P., Ehlers, C., 2006a. Crustal thickening and lateral flow during compression of hot lithospheres, with particular reference to Precambrian times. Terra Nova 18, 72-78.

Cagnard, F., Brun, J.P., Gapais, D., 2006b. Modes of thickening of analogue weak lithospheres. Tectonophysics 421, 145-160.

Cagnard, F., Gapais, D., Barbey, P., 2007, Collision tectonics involving juvenile crust: the example of the southern Svecofennides. Precamb. Res. 154, 125-141.

Chardon, D., Peucat, J.J., Jayananda, M., Choukroune, P., Fanning, M., 2002. Archean granite-greenstone tectonics at Kolar (South India): Interplay of diapirism and bulk inhomogeneous contraction during juvenile magmatic accretion. Tectonics 21, 7-17, doi: 10.1029/2001TC901032.

Chardon, D., Jayananda, M., Chetty, T.R.K., Peucat, J.J., 2008. Precambrian continental strain and shear zone patterns: south Indian case. J. Geophys. Res. 113, B08402, doi: 10.1029/2007JB005299.

Chardon, D., Gapais D., Cagnard, F., 2009. Flow of ultra-hot orogens: A view from the Precambrian, clues for the Phanerozoic. Tectonophysics 477, 105-118.

Choukroune, P., Bouhallier, H., Arndt, N.T., 1995. Soft lithospheres during periods of 
Archaean crustal growth or crustal reworking. In Coward, M., Riss, A. (Eds.). Early

Precambrian Processes: Geol. Soc. London Spec. Pub. 95, 67-86.

Chown, E.H., Daigneault, R., Mueller, W., Mortensen, J.K., 1992. Tectonic evolution of the northern Volcanic Zone, Abitibi belt, Quebec. Can. J. Earth Sci. 29, 2211-2225.

Daignault, R., 1996. Couloirs de déformation de la sous-Province de l'Abitibi: Ministère des Ressources Naturelles, Gouvernement du Québec, Secteur des Mines, Rapport MB 96-33, $111 \mathrm{p}$.

Dubé, B., Gosselin, P., 2007. Greenstone-hosted quartz-carbonate vein deposit. In:

Goodfellow, W.D. (Ed.), Mineral Deposits of Canada: A Synthesis of Major DepositTypes, District Metallogeny, the Evolution of Geological Provinces, and Exploration Methods. Geological Association of Canada, Mineral Deposits Division, Special Publication 5, 49-73.

Fueten, F., Robin, P.Y., 1989. Structural petrology along a transect across the Thompson Nickel Belt, Manitoba: dip-slip at the western Churchill-Superior boundary. Can. J. Earth Sci. 26, 1976-1989.

Ganne, J., De Andrade, V., Weinberg, R.F., Vidal, O., Dubacq, B., Kagambega, N., Naba, S., Baratoux, L., Jessel, M., Allibon, J., 2011. Modern-style plate subduction preserved in the Palaeoproterozoic West African craton: Nature Geoscience DOI: 10.1038/NGEO1321.

Gapais, D., Potrel, A., Machado, N., Hallot, E., 2005, Kinematics of long-lasting Palaeoproterozoic transpression within the Thompson Nickel Belt (Manitoba Canada). Tectonics 24, 1-16.

Gapais, D., Pelletier, A., Ménot, R.P., Peucat, J.J., 2008. Paleoproterozoic tectonics in the Terre Adélie Craton (East Antartica). Precamb. Res. 162, 531-539. 
Gapais, D., Cagnard, F., Gueydan, F., Barbey, P., Ballèvre, M., 2009. Mountain building and exhumation processes through time: inferences from nature and models. Terra Nova, 21, 188-194.

Goscombe, B., 1991. Intense non-coaxial shear and the development of mega-scale sheath folds in the Arunta block, Central Australia: J. Struct. Geol. 13, 299-318.

Hamilton, W.B., 2003. An alternative Earth. GSA Today 3, 4-12.

Hudleston, P.J., Schultz-Ela, D., Southwick, D.L., 1988. Transpression in an Archean greenstone belt, northern Minesota. Can. J. Earth Sci. 25, 1060-1068.

Jaguin, J., Gapais, D., Poujol, M., Boulvais, P., Moyen, J.F., 2012. The Murchison

Greenstone Belt (South Africa): a general tectonic Framework. S. African J. Geol. 115, 63-74, doi:10.2113/gssajg.115.1.74.

Lin, S., Beakhouse, G.P., 2013. Synchronous vertical and horizontal tectonism at late stages of Archean cratonization and genesis of Hemlo gold deposits, Superior craton, Ontario, Canada. Geology 41, 359-362.

Lonka, H., Schulmann, K., Venera, Z., 1998. Ductile deformation of tonalite in the Suomusjarvi shear zone, southwestern Finland. J. Struct. Geol. 20, 783-798.

Martin, R.F., Randrianandraisaina, A., Boulvais P. 2014. Ampandrandawa and similar phlogopite deposits in southern Madagascar: derivation from a silicocarbonatitic melt of crustal origin; J. African Earth Sci., in press.

Morteani, G., Kostitsyn, Y.A., Gilg, H.A., Preinfalk, C. 2013. Geochemistry of phlogopite, diopside, calcite, anhydrite and apatite pegmatites and syenites of southern Madagascar. Evidence for crustal silicocarbonatitic (CSC) melt formation in a Panafrican collisional tectonic setting. Int. J. Earth Sci. 102, 622-645.

Pearton, T.N., Viljoen, M.J. 1986. Antimony mineralisation in the Murchison Greenstone Belt - An overview. In: Anhaeusser, C.R., Maske, S. (Eds.), Mineral Deposits of 
Southern Africa, 293-391.

Pili, E., Ricard, Y., Lardeaux, J.M., Sheppard, S.M.F., 1997. Lithospheric shear zones and mantle-crust connections. Tectonophysics 280, 15-29.

Powell, W.G., Carmichael, D.M., Hodgson, C.J., 1995. Conditions and timing of metamorphism in the Southern Abitibi greenstone belt, Quebec. Can. J. Earth Sci. 32, 787-804.

Putnis, A., 2002. Mineral replacement reactions: from macroscopic observations to microscopic mechanisms. Mineral. Mag. 66, 689-708.

Rey, P., Houseman, G., 2006. Lithospheric scale gravitational flow: the impact of body forces on orogenic processes from Archaean to Phanaerozoic. In: Buiter, S., Schreus, G (Eds.) Analogue and Numerical Modelling of Crustal-Scale Processes. Geol. Soc. London Spec. Pub. 253, 153-167.

Shenberg, D.M., Barnes, H.L., 1989. Solubility of gold in aqueous sulfide solutions from 150 to $350^{\circ} \mathrm{C}$. Geochemica et Cosmochemica Acta 53, 269-278.

Sibson, R.H., Robert, F., Poulsen, H., 1988. High-angle reverse faults, fluid-pressure cycling, and mesothermal gold-quartz deposits. Geology 16, 551-555.

Thébaud, N., Rey, P.F., 2013. Archean gravity-driven tectonics on hot and flooded continents: Controls on long-lived mineralised hydrothermal systems away from continental margins. Precamb. Res, 229, 93-104.

Tremblay, A., 2001. Postmineralization Faults in the Beaufor Gold Deposit, Abitibi Greenstone Belt, Canada: Geometry, Origin, and Tectonic Implications for the Vald'Or Mining District. Economic. Geology 96, 509-524.

Vearncombe, J.R., Barton, J. M., Cheshire, P.E., De Beer, J.H., Stettler, E.H., Brandl, G., 1992. Geology, geophysics and mineralization of the Murchison Schist Belt, Rooiwater Complex and surrounding granitoids. Memoir of the Geological Survey of 
South Africa 81, 139 p.

Windley, B.F., 1995. The evolving continents. Wiley and Sons, Chichester.

Zwanzig, H.V., Macek, J.J., McGregor, C.R., 2007. Lithostratigraphy and Geochemistry

of the High-Grade Metasedimentary Rocks in the Thompson Nickel Belt and Adjacent

Kisseynew Domain, Manitoba: Implications for Nickel Exploration. Economic

Geology 102, 1197-1216.

\section{Figure captions}

Fig. 1. Simplified geological and structural maps of studied areas. (a) Southern Abitibi sub-Province (Quebec) (Au), (b) Murchison belt (South Africa) (Sb), (c) Thompson belt (Manitoba)(Ni). Maps show main zones of supra-crustal deposits, fault zones, ore deposit locations, and simplified foliation trajectories (modified after Chown et al., 1992; Gapais et al., 2005; Böhm et al., 2007; Dubé and Gosselin, 2007; Jaguin et al., 2012).

Fig. 2. Outcrop photographs and sterographic projections (equal area, lower hemisphere) illustrating attitudes of stretching lineations. (a,b) Cadillac fault (photograph shows stretched pebbles in conglomerate, coordinates $48^{\circ} 13^{\prime} 0.45^{\prime}$ 'N, $78^{\circ} 54^{\prime} 29^{\prime \prime}$ W) (lineations from Daigneault, 1996 and our own measurements); (c, d) Murchison belt (photograph shows stretching lineation within the Antimony Line, coordinates $23^{\circ} 51^{\prime} 52$ "S, 3046'33"E) (modified after Jaguin et al., 2012); (e, f) Thompson belt (photograph shows stretching lineation within migmatites, coordinates $55^{\circ} 29^{\prime} 11^{\prime \prime} \mathrm{N}, 98^{\circ} 09^{\prime} 42^{\prime}{ }^{\prime} \mathrm{W}$ ) (modified after Gapais et al., 2005). Mean Fisher orientation and attached 95\% confidence cones are shown in bold. 
Fig. 3. Deformation modes of shortening of a weak continental lithosphere. (a) Sketch summarizing structural patterns and main inferred fluid sources and path-ways during shortening marked by sub-vertical thickening and piling-up of upper-crustals pop-downs within underlying weak ductile crust (structural synthesis after Gapais et al., 2009; Cagnard et al., $2006 \mathrm{a}, \mathrm{b}$ ) (Because of major difference in scales between overall tectonic processes and precise locations of metal depositions, the later are not shown). (b) Example of cross-section of shortened analogue model marked by piling up of popdowns (50\% horizontal shortening) (modified after Cagnard et al., 2006b). 
Figure2

\section{Gapais et al., Fig. 2}
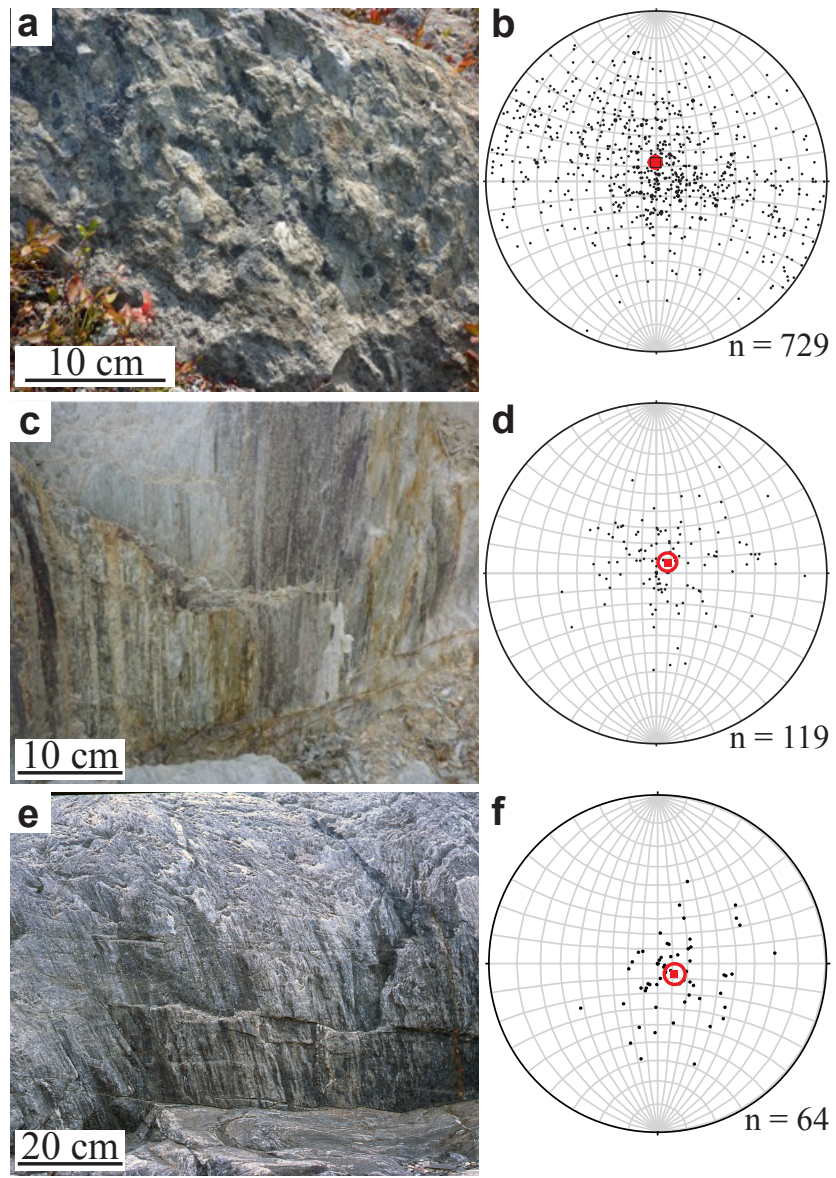
Gapais et al., Fig. 3

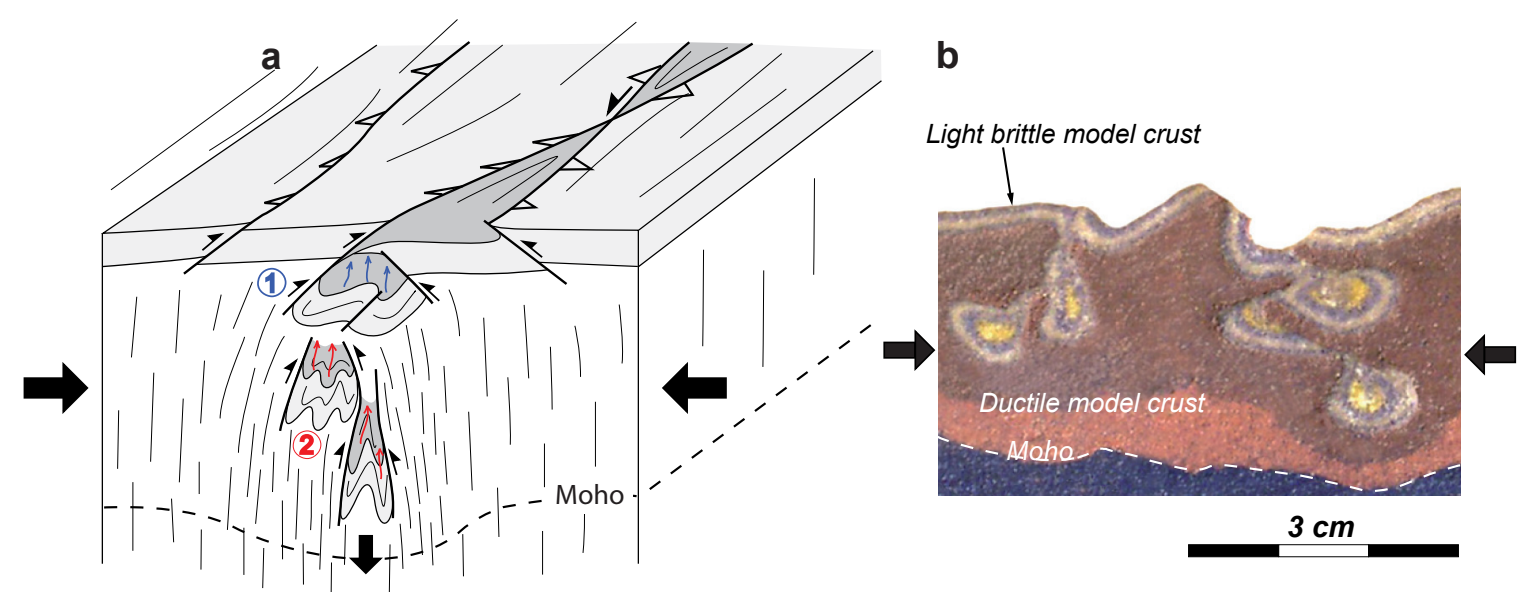

1 compaction and diagenesis

2 metamorphism and partial melting 

Highlights
Click here to download Supplementary material for online publication only: GapaisetalHighlightsrevised.doc

Click here to download Supplementary material for online publication only: GapaisetalHighlightsrevised.doc (2)

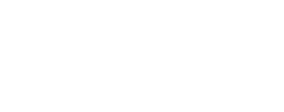

